\title{
How is the Dental Hygiene Status of Preschool Children During the Covid-19 Pandemic? - Tooth Brushing Skills and Characteristics of Parents
}

\author{
Tedi Purnama
}

\section{ABSTRACT}

Background: During the COVID-19 pandemic, preschool children did online teaching and learning at home, so that efforts to promote dental health by health workers were not optimal. This will have an impact on the dental hygiene status of preschool children to be worse. Therefore, the role of parents is needed to pay attention to dental and oral health from an early age.

Aims: This study analyzed the relationship between tooth brushing skills and parental characteristics on the dental hygiene status of preschool children.

\begin{abstract}
Methods: The research design used is descriptive analytic with a cross sectional method approach. The population in this study were students of Sekar Bangsa Kindergarten, Aisyiyah Kindergarten and Bina Insan Karimah Foundation, Pondok Labu Village, South Jakarta City, with the number of samples used was 60 respondents. The independent variables are teeth brushing skills and parental characteristics. The dependent variable is the dental hygiene status of preschool children. The data collection instruments used were questionnaires, observation sheets and free-plaq score examination sheets. Analysis of the data used is Chi Square with a significance level of $p<0.005$.

Results: brushing skills on dental hygiene status showed that the value of $p=0.001(p<0.05)$ and the age of the parents had the value of $p=0.161$, the work of the parents the value of $p=0.083$ and the education of the parents $p=0.282(p>0.05)$. Conclusion: there is a significant relationship between tooth brushing skills on the dental hygiene status of preschool children and there is no relationship between the characteristics of parents on the dental hygiene status of preschool children.
\end{abstract}

Keywords: Dental hygiene status, preschool children, tooth brushing skills.

Published Online: January 13, 2022

ISSN: $2684-4443$

DOI :10.24018/ejdent.2022.3.1.139

T. Purnama*

Department of Dental Health, Poltekkes

Kemenkes Jakarta I, Indonesia.

(e-mail: tedypurnama23@yahoo.com)

*Corresponding Author

\section{INTRODUCTION}

Dental caries is still one of the most common problems not only in adults but also in children [1]. Data from the 2018 Basic Health Research reported that $92.6 \%$ of children aged 5-6 years experienced dental health problems; with a def-t number of 8.43 , it means that the average number of tooth decay is 8 to 9 teeth per child [2]. The World Health Organization (WHO) in 2016 stated that the incidence of caries in children was still 60-90\% [3]. According to research results in European, American and Asian countries, it turns out that $90-100 \%$ of children experience dental caries [4].

As a result of untreated dental caries, several complications will occur such as inflammation and pus in the gums, abscesses in the gum tissue and muscle inflammation in the jawbone and even death in the jawbone, cellulitis, swelling and inflammation in the esophagus, causing difficulty swallowing and inability to swallow, opening the mouth, even causing the heart [5], [6]. This has an impact on poor quality of life, and health problems [7].

Dental caries problems in preschool children are caused by many factors [8]. Including having a penchant for eating sweet foods such as candy and chocolate, dental and oral hygiene, habits that are not in accordance with health such as eating food, chewing candy habits, drinking milk before bed using bottled milk [9]. Which is too long (drinking), as well as the role of parents who pay less attention to dental and oral health from an early age [10]. Another factor that affects one of them is the behaviour of people who do not realize the importance of maintaining oral health [11]. It can be seen that the behaviour of brushing teeth of the population aged 3 years is $2.8 \%$ who behaves to brush their teeth properly [2].

The skill of brushing teeth properly and correctly is an important factor for dental and oral health care [7]. Brushing teeth is a simple act of removing plaque and food debris with a toothbrush and toothpaste, because plaque and food debris 
are the main causes of dental caries [12]. This is reinforced by Purnama et al. research proving that preschool do not yet have skills in brushing their teeth [13]. The research of Ngatemi et al. also proves that in brushing teeth, early childhood does not yet have the ability to brush their teeth properly at home [14].

During the COVID-19 pandemic, preschool age children must carry out online teaching and learning with parental monitoring at home, so that the maintenance of their dental health depends on their parents, especially mothers as the closest people to their children [15]. Starting to grow teeth is an important process of a child's growth. Parents, especially mothers, must know how to take care of their children's teeth and also have to guide their children how to brush their teeth properly and correctly. Even though they still have baby teeth, a child must get serious attention from their parents because milk teeth will affect the growth of the child's permanent teeth. However, many parents think that milk teeth are only temporary and will be replaced by permanent teeth so they often assume that damage to milk teeth caused by poor oral hygiene is not a problem [16]. Poor oral and dental hygiene causes the accumulation of plaque containing various kinds of bacteria, including Streptococcus mutans as the main cause of caries [17].

Several studies have proven that children with moderate criteria for dental hygiene status are 31 people $(51.7 \%)$, with poor criteria 29 people $(48.3 \%)$, and very good criteria $(0 \%)$ and good criteria $(0 \%)$ because there are no students who have very good criteria and good criteria [18]. Ngatemi research proves that there is a relationship between the independence of brushing children's teeth and the plaque scores of preschool children. So it can be interpreted that preschool children who are not skilled in brushing their teeth have a worse dental hygiene status than those who are skilled [19].

\section{MAterials AND MethodS}

This research is an analytic observational study with a cross-sectional approach. The research was carried out on children aged 5-6 years at Sekar Bangsa Kindergarten, Aisyiyah Kindergarten and Bina Insan Karimah Foundation, Pondok Labu Village, South Jakarta City. The research sample was taken using a total purposive sampling technique, as many as 60 respondents. The dependent variable in this study was the brushing skills and characteristics of parents and the independent variable was the dental hygiene status of preschool children.

The collection of data on brushing skills was measured by brushing teeth checklist, validity and reliability tests have been carried out by the same previous researcher who examined teeth brushing skills [20]. Characteristics of parents were measured using a questionnaire. Dental hygiene status is measured by standard dental hygiene examination using a free plaque index measuring instrument [19]. The stages of the activity include: before checking the dental hygiene status of the child, the mentor/parent fills out an informed consent form first as an agreement that he is willing to be a research respondent. Then give a questionnaire sheet to parents and check the dental hygiene status of all children in turn and make observations about brushing their teeth.
Data analysis was carried out using the SPSS statistical program for univariate analysis and presented in the form of a frequency distribution and bivariate analysis with chisquare to measure the relationship between tooth brushing skills and parental characteristics to the dental hygiene status of preschool children and to measure strength using Spearman's.

\section{RESULTS}

TABLE I: FREQUENCY DISTRIBUTION OF RESPONDENT CHARACTERISTICS

\begin{tabular}{cccc}
\multicolumn{4}{c}{ CHARACTERISTICS } \\
\hline \hline No. & Variable & $\mathrm{N}$ & Percentage (\%) \\
\hline \hline 1 & Age & 25 & 41.7 \\
& 5 years & 35 & 58.3 \\
& 6 years & & \\
2 & Gender & 27 & 45.0 \\
& Laki-laki & 33 & 55.0 \\
& Perempuan & & \\
3 & Parent's age & 23 & 38.3 \\
& <30 years & 37 & 61.7 \\
& > 30 years & & \\
4 & Parents' job & 11 & 18.3 \\
& Private & 5 & 8.3 \\
& Entrepreneur & 44 & 73.3 \\
& Housewives & & \\
5 & Parent's education & 14 & 23.3 \\
& Junior high school & 29 & 48.3 \\
& Senior High School & 17 & 28.3 \\
\hline \hline
\end{tabular}

Table I shows that the characteristics of respondents based on age and gender in children are mostly women aged 6 years and parents aged $>30$ years, having senior high school and working as housewives.

TABLE II: FREQUENCY DISTRIBUTION BRUSHING SKILLS

\begin{tabular}{cccc}
\hline \hline No. & Brushing skills & $\mathrm{N}$ & Percentage (\%) \\
\hline \hline 1 & Good & 13 & 21.7 \\
2 & Less & 47 & 78.3 \\
& Total & 60 & 100 \\
\hline \hline
\end{tabular}

Table II shows that 13 respondents (21.7\%) had good brushing skills and 47 respondents $(78.3 \%)$ had less brushing skills.

TABLE III: FREQUENCY DISTRIBUTION OF DENTAL HYGIENE STATUS

\begin{tabular}{cccc}
\hline \hline No. & Dental hygiene status & $\mathrm{N}$ & Percentage (\%) \\
\hline \hline 1 & Good & 3 & 5.0 \\
2 & Bad & 57 & 95.0 \\
& Total & 60 & 100 \\
\hline \hline
\end{tabular}

Table III shows that 3 respondents $(5.0 \%)$ with good criteria for dental hygiene status and 57 respondents $(95.0 \%)$ with bad criteria for dental hygiene status.

Table IV shows that the chi-square analysis of parental characteristics (parental age, parental job, parental education) on dental hygiene status show that $\mathrm{p}>0.05$ means that there is no relationship between parental characteristics and preschool children's dental hygiene status. Meanwhile, the pvalue of brushing teeth skills was $p=0.001(p<0.05)$, meaning that there was a significant relationship between toothbrushing skills and the dental hygiene status of preschool children. And the correlation test to see the closeness of the relationship between the two variables using the Spearman test was obtained $=0.303$ which means that there is a sufficient correlation between brushing skills and dental hygiene status of preschool children. 
TABLE IIV: RESULTS OF CHI-SQUARE ANALYSIS BETWEEN TOOTH BRUSHING SKILLS AND CHARACTERISTICS OF PARENTS WITH DENTAL HYGIENE STATUS

\begin{tabular}{|c|c|c|c|c|c|c|c|c|c|}
\hline \multirow{3}{*}{ Variabel } & \multirow{3}{*}{ Criteria } & \multicolumn{4}{|c|}{ Dental hygiene status } & \multirow{2}{*}{\multicolumn{2}{|c|}{ Total }} & \multirow{3}{*}{$\mathrm{p}$-value } & \multirow{3}{*}{$\rho^{*}$} \\
\hline & & \multicolumn{2}{|c|}{ Good } & \multicolumn{2}{|c|}{$\mathrm{Bad}$} & & & & \\
\hline & & $\overline{\mathrm{n}}$ & $\%$ & $\overline{\mathrm{n}}$ & $\%$ & $\overline{\mathrm{n}} \mathrm{n}$ & $\%$ & & \\
\hline \multirow{2}{*}{ Brushing skills } & Good & 3 & 5.0 & 10 & 16.7 & 13 & 21.7 & \multirow{2}{*}{0.001} & \multirow{2}{*}{0.303} \\
\hline & Less & 0 & 0 & 47 & 78.3 & 47 & 78.3 & & \\
\hline \multirow{2}{*}{ Parent's age } & $\leq 30$ years & 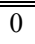 & 0 & 23 & 38.3 & 23 & 38.3 & \multirow{2}{*}{0.161} & \multirow{2}{*}{0.178} \\
\hline & $>30$ years & 3 & 5.0 & 34 & 56.7 & 37 & 61.7 & & \\
\hline \multirow{3}{*}{ Parent's job } & Privat & 2 & 3.3 & 9 & 15.0 & 11 & 18.3 & \multirow{3}{*}{0.083} & \multirow{3}{*}{0.038} \\
\hline & Entrepreneur & 0 & 0 & 5 & 8.3 & 5 & 8.5 & & \\
\hline & Housewives & 1 & 1.7 & 43 & 71.7 & 44 & 73.3 & & \\
\hline \multirow{3}{*}{$\begin{array}{l}\text { Parent's } \\
\text { education }\end{array}$} & Junior High school & 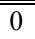 & 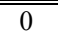 & 14 & 23.3 & 14 & 23.3 & \multirow{3}{*}{0.283} & \multirow{3}{*}{0.043} \\
\hline & Senior High School & 1 & 1.7 & 28 & 46.7 & 29 & 48.3 & & \\
\hline & College & 2 & 3.3 & 15 & 25.0 & 17 & 28.4 & & \\
\hline
\end{tabular}

\section{DISCUSSION}

The results of the research on the characteristics of respondents in preschool children were mostly women (55\%) and those aged 6 years $(58.3 \%)$. This is in accordance with the age limit for preschool children who are generally aged from 4-6 years. The preschool period (4-6 years) is a phase when children begin to separate from their parents and begin to interact with their environment [11]. The developmental task in preschool children is to achieve sufficient autonomy, fulfill and handle oneself without full parental intervention. At this stage, children can be involved in activities or household chores to help parents [21].

The results of the parental characteristics study showed that most of the parents aged $>30$ years were 37 people (61.7\%), 29 people had high school education $(48.3 \%)$ and 44 people were working as housewives $(73.3 \%)$. Parents, especially mothers, are the closest people to where children learn to grow and develop. Children learn from parents to be able to meet their own basic needs, thus if parents set an example of good behaviour, then children will also follow the behaviour of their parents. Applying an example or model in brushing teeth is one of the best ways to prevent dental caries [22], [23]. At the age of $>30$ years, including early adulthood where parents can feel or recognize the needs of their children than the age of young mothers who have not been able to feel or recognize the needs of their children [11].

The results showed that most of the respondents had poor tooth brushing skills as many as 47 respondents $(78.3 \%)$. This is because the majority of respondents do not know about brushing their teeth properly, in fact all children only brush their teeth in a back-and-forth motion for the entire surface. The factor of children's less of knowledge about tooth brushing techniques can affect children's skills in brushing teeth, possibly due to limited information and low awareness of preschool children about the importance of dental and oral hygiene [24]. The results of this study are also in accordance with Purnama research proves that preschool children are not skilled in brushing their teeth [13].

The results of the study on dental hygiene status obtained that most of the respondents were 57 respondents $(95.0 \%)$ with poor criteria for dental hygiene status. This is possible because preschool children do not yet have the skills to brush their teeth, it can be seen that the results of the study show that most $78.3 \%$ of children are not skilled at brushing their teeth independently. The results of this study are relevant to Ngatemi's study which showed that the majority of the dental and oral hygiene status of preschool children were $90.6 \%$ poor criteria [19]. Brushing teeth is the most important effort to prevent or reduce the formation of plaque on the tooth surface. Brushing teeth aims to clean soft deposits on the surface of the teeth and gums and is a preventive measure towards success and optimal oral health [25].

The results of the chi-square analysis between tooth brushing skills and dental hygiene status showed that the value of $p=0.001(p<0.05)$, meaning that there was a significant relationship between tooth brushing skills and preschool children's dental hygiene status. Strengthened by the correlation test to see the closeness of the relationship between two variables using the Spearman test, it was obtained that $=0.303$ means that there is a sufficient correlation between brushing skills and dental hygiene status of preschool children. This is due to the less of tooth brushing skills in children. This is supported by Ngetemi's research which proves that teeth brushing skills can also affect dental and oral hygiene [19]. Reinforced by Arianto et al. the skill of brushing teeth properly and correctly is an important factor for children's dental problems that often occur are caused when children cannot clean or are skilled at brushing their teeth properly [12]. Caries or cavities are the most common problems children complain about. The cause is plaque that is not cleaned so that bacteria appear [26].

The simplest way to keep your teeth and mouth clean is by brushing your teeth. Brushing teeth using a combination technique is the most effective in reducing plaque scores. In addition, proper brushing of teeth takes at least 2 minutes and the right time after breakfast and before going to bed at night. The technique for brushing teeth is good and correct for preschool, namely, prepare a toothbrush and toothpaste that contains flour, the amount of toothpaste is the size of a peanut, rinse before brushing teeth, brush the surface of the teeth facing the cheeks and lips in a circular motion, brush the surface of the teeth. used for chewing in a back and forth motion, brush the surface of the teeth facing the palate and tongue with a prying motion, brush the surface of the tongue after all tooth surfaces have been brushed, rinse only once, clean the toothbrush with water and store the toothbrush in an upright position, head brush is on top [27].

The results of the chi-square analysis between parental age, parental occupation, parental education on dental hygiene status showed that the $p$ value $>0.05$ means that there is no relationship between parental characteristics and dental hygiene status of preschool children. This shows that what affects the dental hygiene of preschool is the brushing skills 
of their own children.

\section{CONCLUSION}

Based on the results of the study, it can be concluded that:

1. Tooth brushing skills, most preschool children have less tooth brushing skills

2. Dental hygiene status, most preschool children have bad criteria for dental hygiene status

3. There is a significant relationship $(p<0.001)$ between brushing skills and dental hygiene status of preschool children

4. There is no relationship between the characteristics of parents on the dental hygiene status of preschool children.

\section{ACKNOWLEDGMENT}

The author would like to thank the Poltekkes Kemenkes Jakarta I which provides funding lecturer research

\section{CONFLICT OF INTEREST}

Authors declare that they do not have any conflict of interest.

\section{ETHICAL CLEARANCE}

All participants were signed the informed consent prior to the data collection.

\section{REFERENCES}

[1] Purnama T, Ngatemi IF, Widiyastuti R. Model Mentoring Teachers and Parents as an Efforts for Brushing Teeth Behavior in Preschool Children. Indian J Forensic Med Toxicol. 2020; 14: 3511.

[2] Kemenkes RI. Basic Health Research 2018. Jakarta. 2018.

[3] Jurgensen N, Petersen PE. Promoting oral health of children through schools-Results from a WHO global survey 2012. Community Dent Heal. 2013; 30: 204-18

[4] Foley MA, Sexton C, Spencer AJ, Lalloo R, Do LG. Water fluoridation, dental caries and parental ratings of child oral health. Community Dent Oral Epidemiol. 2021.

[5] Ryan P, McMahon G. Severe dental infections in the emergency department. Eur J Emerg Med. 2012; 19: 208-13.

[6] Olsen I, van Winkelhoff AJ. Acute focal infections of dental origin. Periodontol 2000. 2014; 65: 178-89.

[7] Purnama T, Ngatemi N, Sofian R, Kasihani NN, Re PR, Nurbayani S The 5 Days Gosgi model as an effort to establish the independence of brushing teeth for early childhood in school. Qual J Health. 2020; 14: $19-24$.

[8] Ngatemi N, Kristianto J, Widiyastuti R, Purnama T, Insani RL. History of giving formula milk with def-t index to early childhood a Pertiwi IV Kindergarten Pondok Labu. JDHT J Dent Hyg Ther. 2020; 1: 6-11

[9] Prakash P, Subramaniam P, Durgesh BH, Konde S. Prevalence of early childhood caries and associated risk factors in preschool children of urban Bangalore, India: A cross-sectional study. Eur J Dent. 2012; 6: $141-52$.

[10] Sari DN, Laela DS, Restuning S. The level of knowledge of parents with the incidence of nursing bottle caries. JDHT J Dent Hyg Ther. 2020;1:40-4.

[11] Suciari A, Arief YS, Rachmawati PD. The role of parents in guiding tooth brushing with the incidence of dental caries in preschool children. Pediomaternal Nurs J. 2016; 3.

[12] Arianto A, Shaluhiyah Z, Nugraha P. Tooth brushing Behavior in Grade V and VI Elementary School Students in Sumberejo District. $J$ Indonesian Health Promotion. 2014;9:127-35.

[13] Purnama T, Rasipin R, Santoso B. The Effect of Tedi's Behavior
Change Model Training on Teachers and Parents on the Skills of Brushing the Teeth of Preschool Children. Qual J Health. 2019; 13: $75-81$.

[14] Ngatemi, Purnama T. Dental Health Handbook as Parents Monitoring in the Formation of Independence for Brushing Teeth in Early Childhood. Indian J Public Heal Res Dev. 2020; 11.

[15] Elyana L, Fitriati R. PAUD Technomedia Management in the Covid 19 Pandemic era. Sentra Cendekia 2021; 2: 6-11.

[16] Kasihani NN, Ngatemi, Purnama T. Determinants of Parental Behavior in Maintaining Deciduous Teeth in Early Childhood: A Cross Sectional Study, Eur J Mol Clin Med. 2021; 8(2): 1248-1255.

[17] Ngatemi, Purnama T. Counseling with Tooth Brushing Demonstration Method as an Effort to Improve Tooth Brushing Skills and the Status of Dental and Oral Hygiene in Early Childhood at School. Med Leg Updat. 2021; 21: 684-7.

[18] Zulfikri Z, Huda ZI. The relationship between dental and oral hygiene index and dental caries index in SDN 03 Pakan Kurai students, Guguk Panjang District, Bukittinggi City. J Dental Health. 2017; 4: 55-62.

[19] Ngatemi, Purnama T, Kasihani NN. Independence of Brushing Teeth to Free-Plaque Score in Preschool Children: A Cross Sectional Study. Indian J Forensic Med Toxicol. 2021; 15: 3722-7.

[20] Purnama T, Rasipin R, Santoso B. The Effect of Tedi's Behavior Change Model Training on Teachers and Parents on the Skills of Brushing the Teeth of Preschool Children. Qual J Health. 2019; 13: 75-81.

[21] Izzaty RE. Preschooler behavior. Elex Media Komputindo; 2017.

[22] Heinrich CJ. Parents' employment and children's wellbeing. Futur Child. 2014: 121-46.

[23] Sariningsih E. Taking care of children's teeth from an early age. Jakarta Elex Media Komputindo 2012.

[24] Pudentiana RR, Purnama T, Tauchid SN, Prihatiningsih N Knowledge of Oral and Dental Health Impacts the Oral Hygiene Index Simplified (OHI-S) of Primary School Children. Indian J Forensic Med Toxicol. 2021; 15: 2179-83.

[25] Hiranya MP, Eliza H, Neneng N. The science of preventing diseases of hard tissues and supporting tissues of the teeth. Jakarta EGC 2011;104.

[26] Mathur VP, Dhillon JK. Dental caries: a disease which needs attention. Indian J Pediatr. 2018; 85: 202-6.

[27] Kemenkes RI. School Dental Health Guidelines (UKGS). Jakarta. 2012 